Source: Ministry of Foreign Affairs (http://mfa.gov.af/en/news/4598)

Publish Date: Nov 03, 2011

\title{
ISTANBUL PROCESS ON REGIONAL SECURITY AND COOPERATION FOR A SECURE AND STABLE AFGHANISTAN
}

November 2, 2011

1. We have convened in İstanbul on 2 November 2011, under the leadership of H. E. Mr. Hamid Karzai, President of the Islamic Republic of Afghanistan, and H. E. Mr. Abdullah Gül, President of the Republic of Turkey, and at the joint invitation of H. E. Mr. Zalmai Rassoul, Foreign Minister of the Islamic Republic of Afghanistan and H. E. Mr. Ahmet Davutoğlu, Foreign Minister of the Republic of Turkey, to reaffirm our strong commitment to a secure, stable and prosperous Afghanistan in a secure and stable region.

2. We affirm the commitments enshrined in the 2002 Kabul Declaration of Good Neighbourly Relations and agree that promoting regional security and cooperation requires measures to build confidence and trust among countries. Hence, we will be guided by the following set of common principles and commitments, which shall include, but not be limited to:

- Recognition of the central role of the United Nations in international affairs;

- Equal and indivisible security;

- Respect for the territorial integrity of States;

- Non-intervention in the internal affairs of other states;

- Support for the stability and peace in Afghanistan, as well as respect for Afghanistan's sovereignty, unity and territorial integrity;

- Continued support for the Government and people of Afghanistan, as they develop their country, reconstruct their economy, and further improve their human capital;

- Resolutely combating and eliminating terrorism in all its forms and manifestations and violent extremism, and preventing safe havens for terrorists and terrorism in the region;

- Dismantling terrorist sanctuaries and safe havens, disrupting all financial and tactical support for terrorism;

- Acknowledging that terrorism poses a threat to international peace and security as well as a common challenge to our societies, to the region, and that it can only be addressed through the concerted efforts of all countries;

- Facilitating the voluntary, dignified, and orderly return of Afghan refugees; 
- Support for an inclusive Afghan national process of reconciliation, in accordance with the Constitution of Afghanistan and in ways which is Afghan-led, Afghan-owned and Afghan-driven;

- Constructive and supportive relationship between countries of the region;

- Refraining from the threat or use of force and not to allow one's territory to be used against another;

- Elimination of illicit drug production, trade and trafficking;

- Preventing the cultivation and production of narcotics;

- Preventing the activities of extremist organizations and organized crime networks through enhanced cooperation;

- Supporting and promoting law enforcement cooperation;

- Peaceful settlement of disputes in accordance with the United Nations Charter and international law;

- Fulfillment of obligations under international law;

3. Afghanistan and its international and regional partners will seek to develop and coordinate contributions to advance the above-stated principles.

4. We recognize Afghanistan's role as the land bridge in the 'Heart of Asia', connecting South Asia, Central Asia, Eurasia and the Middle East, and reaffirm our support in the strongest possible terms to the secure, stable and peaceful future of Afghanistan. We welcome Afghanistan's willingness and determination to use its regional and historical position to do its part to promote security and peaceful economic cooperation in the region.

5. We respect Afghanistan as a sovereign, independent, democratic state, which constitutes an integral component of the peace, well-being and prosperity of the region and beyond. We support the Government of Afghanistan's priorities on the issues of security, governance, economy, counter-terrorism, counter-narcotics and regional cooperation.

6. We re-emphasize our determination to help Afghanistan fight terrorism and illicit drugs. In return, Afghanistan re-iterates its commitment to respect the territorial integrity of its neighbours, and to assure them that its relations with any state, on which it will be transparent, will not be directed against any third party. Afghanistan also reconfirms its will and determination to combat terrorism in all its forms and manifestations, strengthen its economy, especially by ensuring good governance, promotion of investments, and addressing corruption, fight radicalism and narcotrafficking, respect human rights, in particular the rights of women, and to work together with its friends and partners for enhanced regional co-operation.

7. We reiterate our resolve to combat terrorism, extremism and separatism in all its forms and 
manifestations, the financing, harbouring, training and equipping of such activities, and acknowledge that terrorism, extremism and separatism pose a common challenge that can only be addressed through concerted efforts by countries of the region and the broader international community.

8. We will strengthen cooperation with Afghanistan, as well as regional and international cooperation, to counter the threat posed by the illicit production, trafficking, and consumption of drugs, in accordance with the principle of common and shared responsibility. Cooperation in combating the illicit drug production, trafficking and consumption should be exercised in a comprehensive manner and comprise poppy and cannabis crops eradication, elimination of drug laboratories, interception of drug caravans, detention of drug traffickers, freezing proceeds from illicit drugs, diversion of drug precursors, as well as introduction of alternative agriculture projects and strengthening measures directed at reduction of the level of drugs consumption in regional and international markets.

9. In assisting Afghanistan, we endorse its efforts at promoting an inclusive reconciliation process and welcome and support the efforts of the High Peace Council, and the implementation of the Afghan Peace and Reintegration Program. We strongly condemn the heinous terrorist attack which took the life of the former President and Head of the High Peace Council, Professor Burhanuddin Rabbani. We will continue to support Afghan-led efforts to reconcile and re-integrate those Afghan militant elements who renounce violence, cut links with terrorist groups, and accept the Afghan Constitution. We remain convinced that a peaceful Afghanistan, with functioning institutions and strengthened security forces, is key to a successful regional cooperation. We remind that the international community and the region are not separated and emphasize that we all have a stake in the security and stability of the region.

10. We mark our full support to the ongoing process of transition of responsibility for providing security in Afghanistan from ISAF/NATO to ANSF in the framework of the 'Kabul Process'. We remain convinced that progress to be made between now and 2014, when transition will be completed, will make a decisive impact on the future course of efforts underway in Afghanistan. However, transition should assist Afghanistan and development of its relevant structures with a sustained support in the form of long term commitments to be made by regional and international partners. We welcome ongoing efforts by the Government of Afghanistan and its regional partners to foster trust and cooperation with each other as well as relevant cooperation initiatives developed by the countries concerned and regional organizations. The promotion of a sound regional cooperation in the 'Heart of Asia' will be an important contribution to these efforts. In this context, enhanced trade connectivity along historical trade routes will also constitute an added value and will require conducive regional environment.

11. We recognise that Afghanistan is today at a critical juncture. It still faces significant security, economic, and development challenges, which are of an interconnected nature. These challenges cannot be addressed without building upon the already constructive support of Afghanistan's regional and international partners. The efforts to meet these challenges are most effective when they are Afghanowned and driven, and supported by all partners and pursued in a transparent and constructive manner.

12. While not all challenges specifically affect each country in similar degree, no single state or international organization can deal with these challenges by itself. A concerted effort towards stability and prosperity is needed. Consequently, regional and international cooperation are indispensable to address challenges. 
13. We declare our readiness to engage in sincere, result-oriented cooperation at all levels, which will not just help Afghanistan, but will also be beneficial to security and prosperity in the region as a whole. We welcome the central and impartial role of the United Nations, in line with the Security Council mandate, and we recognize the important role of the Organization for Islamic Cooperation, the Shanghai Cooperation Organization, the South Asian Association for Regional Cooperation, the Regional Economic Cooperation Conference on Afghanistan, the Conference on Interaction and Confidence Building Measures in Asia, the Economic Cooperation Organization, the Eurasian Economic Union, the Collective Security Treaty Organisation, the United Nations Special Programme for the Economies of Central Asia, and the Central Asia Regional Economic Cooperation in strengthening regional security and promoting regional cooperation. We welcome the participation of Afghanistan in the South Asian Association for Regional Cooperation and in the Conference on Interaction and Confidence Building Measures in Asia, the Organization for Security and Cooperation in Europe, as well as its application to obtain the status of observer state with the Shanghai Cooperation Organization.

14. Similarly, we also positively take note of those bilateral, trilateral and quadrilateral initiatives between Afghanistan and the regional countries that could contribute to the improvement of regional cooperation. We welcome and support all these mechanisms, organisations and processes that add value to regional dimension. We also welcome various efforts aimed at intensifying cooperation and dialogue between Afghanistan and regional countries, recognising the intertwined nature of various challenges faced by all countries in the region. Our regional cooperation vision is not intended to substitute them, but to build synergy between these efforts.

15. These fundamental frameworks and principles of cooperation among countries are unequivocally pertinent in dealing with challenges. We note the value of a more coherent and structured approach to individual initiatives. We pledge to give strong emphasis and further impetus to the ongoing regional cooperation endeavours.

16. With this understanding, based on the principles, including guarantees of territorial integrity, sovereignty and refraining from the threat or use of force to resolve disputes; guarantees for nonintervention in the internal affairs of other States; and peaceful settlement of disputes according to international law, stated in this document, we will endeavour to build confidence through broad ranging and effective Confidence Building Measures (CBMs), where appropriate and based on self-differentation basis, which may include, but not be limited to, the areas listed hereafter.

A) In the political and security field:

- Enhanced cooperation for fighting terrorism, including through exchange of information;

- Participation in Civil Emergency Planning to assess risks and reduce vulnerability of the civil population to terrorism;

- Enhancement of cooperation among Afghanistan and its immediate neighbours for effective border controls; 
- Creation or enhancement of conditions conducive to the voluntary and safe return of refugees, in a dignified and orderly manner;

- Exchange of information regarding forces responsible for counter-terrorism operations and facilitate contacts among them as appropriate;

- Co-operation and interaction among regional countries in the area of counter narcotics and the trafficking of illegal goods and lethal substance, and their precursors, including enhancing bilateral efforts to prevent illicit movement of personnel and material across international borders.

- Development of joint guidelines for cooperation in the field of disaster management;

B) In the economic field:

- Build, where appropriate, on the model of the Afghanistan-Pakistan Transit Trade Agreement, ways to expand trade across the region;

- Trade facilitation strategy - The development of a coherent strategy to develop a regionally coherent trade and border management;

- Preferential Trade Agreement within the region without prejudice to existing trading agreements;

- Establishment of databases and a system of data exchange in trade and economic spheres;

- Improvement of the exchange of information on commercial opportunities and specific trading conditions;

- Improvement in the provisions for the settlement of commercial disputes, including various forms of arbitration;

- A strategy to encourage participation of the private sector in regional development programs, including through private sector-public sector joint ventures;

- Exchange of information on development of international tourism and tourist infrastructure and assistance in establishing and strengthening contacts;

- Exchange of information regarding suspicious financial transactions, illegal financial operations and assistance in establishing and strengthening contacts between appropriate authorities;

- Facilitation of the development of co-operation in the various field of environment;

- Improvement of business contacts and facilities;

- Encourage the establishment of a framework for enhanced cooperation among Chambers of Commerce; 
- Training of personnel in various fields of economic activity;

- The development of a coherent strategy to develop and maintain a regionally connecting infrastructure, with support from international partners;

- Encouraging Afghanistan's role as a land-bridge, connecting the region through cooperation and completion of bridges on trans-boundary rivers, roads and railway networks; in this connection, focusing on construction of new automobile bridges over the Panj River in Kokul and Ayvaj fields of Tajikistan and supporting the implementation of the project on a railway route from East, Central, South and West Asia and to the sea routes through Kyrgyzstan, Tajikistan and Afghanistan with existing UzbekistanAfghanistan railway being connected to a prospective Kazakhstan-Turkmenistan-Afghanistan railway, and supporting the implementation of the project on a railway route from Iran to Afghanistan, the Khaf-Herat Railway;

- Co-operation on easier flow of energy resources within, from and across the region, especially with regard to electricity, minerals, oil and gas, including their exploitation and transit, through regional projects, such as TAPI, and CASA-1000 project which has to be implemented with a broader financial contribution, as well as the World Bank, Asian Development Bank and the Islamic Development Bank;

- Wider support for Tajikistan`s efforts to conduct the 5th Regional Economic Cooperation Conference on Afghanistan (RECCA V) which is planned to be held on March 26-27, 2012 in Dushanbe. Amongst other agenda items, the Conference will consider the proposal from Afghanistan and Tajikistan on enhancing trade connectivity along historical trade routes. On the margins of the RECCA V, we support the organization of a business forum and a forum of scientists and researchers.

- Exploring the possibility of cooperation in the development of hydroelectric power and in the sphere of water management without prejudice to existing agreements;

- Consider, wherever appropriate and mutually agreed, development of large-scale irrigation works without prejudice to existing agreements;

- A more effective regional cooperation in the agricultural and rural fields;

- The development of infrastructure around the main ports and linking them via road and railroad for shipment of goods and energy to and from Central Asia, South Asia, Eurasia and the Black Sea.

C) In the education field:

- Setting up a structured regional education exchange programme with places reserved in universities for students from neighbouring States within the region;

- Broadening cooperation and exchanges in the fields of education and science on a short or long-term basis; 
- Expansion of links between State institutions and non-governmental bodies whose activities are concerned with questions of education and science and including scientific exchanges, exchange of students, joint events;

- Ensure that radical and hatred references are removed from education curriculum;

- Reform the curricula that promote extremism.

- Promotion of the role of mass media as a driver for democratic development and mutual understanding, and to spread messages of peace, harmony and tolerance;

- Establishing a multi-disciplinary professional and technical training Center in Tajikistan which is aimed at preparing civilian specialists for the needs of the Afghanistan economy, with support of international community.

D) In the cultural field:

- Joint projects aimed at disseminating information on various cultures and traditions in the region;

- Co-operation in preserving valuable cultural, historical, archaeological and religious assets;

- A common fight by all nations in the region against all forms and manifestation of violence;

- A joint effort to promote the true nature of Islam as a religion of peace, tolerance and human accomplishment;

- Promotion of inter-faith and intra-cultural dialogue.

E) In the legal field:

- Considering, where apropriate and on the basis of reciprocity, relaxation of visa regimes;

- Considering relaxation of rules and restrictions at border crossings for legitimate travelers on the basis of reciprocal arrangements;

- Promotion of law enforcement cooperation;

17. Through the İstanbul Process, we reaffirm our commitment to strengthening regional security and cooperation, including for the purpose of building a secure and stable Afghanistan. To that end, we have decided to redouble and better coordinate our efforts through bilateral channels and existing multilateral frameworks and future meetings at Ministerial and technical level. The Istanbul Process will be developed and marked by consensus decision making of participating states. 
18. In this regard, we will continue to exchange views on ways and means to implement our decisions.

19. As the first follow-up on the İstanbul Conference, we have decided to meet again at Ministerial level in Kabul in June 2012.

20. The Kabul Ministerial meeting will be preceded by a preparatory meeting at technical level chaired by Afghanistan. To that effect, Afghanistan will circulate a concept paper by the end of January 2012, outlining the agenda of the meeting.

21. Having stated the above, we recognise that the challenge we intend to meet remains considerable. But, through these confidence building measures, we are aiming at a new mindset of cooperation in the region.

22. The ambitious objective of enhanced regional cooperation, with and around Afghanistan, will need to overcome many hurdles. However, the benefits for Afghanistan and its region will reward this ambition and be worth the endeavours.

23. The participants to the İstanbul Conference wish to express their gratitude to the Republic of Turkey for the generous hospitality and commitment to promoting regional cooperation.

Adopted on 2 November 2011 by the 'Heart of Asia' Countries which consist of the Islamic Republic of Afghanistan, the People's Republic of China, the Republic of India, the Islamic Republic of Iran, the Republic of Kazakhstan, the Kyrgyz Republic, the Islamic Republic of Pakistan, the Russian Federation, the Kingdom of Saudi Arabia the Republic of Tajikistan, the Republic of Turkey, Turkmenistan, and the United Arab Emirates.

Welcomed and supported by the Commonwealth of Australia, Canada, the Arab Republic of Egypt, the Republic of France, the Federal Republic of Germany, Republic of Italy, Japan, Norway, Republic of Poland, Spain, Sweden, the United Kingdom and the United States as well as the United Nations, Economic Cooperation Organization, Organization for Security and Cooperation in Europe, North Atlantic Treaty Organization, Shanghai Cooperation Organization, South Asian Association for Regional Cooperation, Organization for Islamic Cooperation, the European Union, the Conference on Interaction and Confidence Building Measures in Asia. 